\title{
Effects of Inhibitors on Mitochondrial Adenosine Triphosphatase of Tetrahymena pyriformis ST
}

\author{
By MARK D. UNITT*† AND DAVID LLOYD \\ Department of Microbiology, University College, Newport Road, Cardiff CF2 1TA, U.K.
}

(Received 5 February 1981; revised 6 April 1981)

\begin{abstract}
Mitochondrial adenosine triphosphatase (ATPase) of the ciliate protozoon Tetrahymena pyriformis $\mathrm{ST}$ is completely inhibited by antiserum prepared against $\mathrm{F}_{1}$-ATPase purified from Schizosaccharomyces pombe, and by naturally occurring inhibitor proteins from this yeast and from bovine heart mitochondria. An ATPase inhibitor protein is also present in extracts of $T$. pyriformis. Mitochondrial ATPase of $T$. pyriformis is only partially inhibited by the $\mathrm{F}_{0}$-ATPase inhibitors $N, N^{\prime}$-dicyclohexylcarbodiimide, oligomycin, leucinostatin, triethyltin sulphate and venturicidin, and (at high titres) by the $\mathrm{F}_{1}$-ATPase inhibitors Dio-9, efrapeptin, 4-chloro-7-nitrobenzofurazan and spegazzinine. Aurovertin, citreoviridin and quercetin were not inhibitory. Resistance to inhibitors distinguishes this mitochondrial ATPase from all those previously examined.
\end{abstract}

\section{INTRODUCTION}

The adenosine triphosphatases (ATPases) of protozoa have been less well studied than those in yeast and mammalian systems. Tetrahymena pyriformis possesses $(a)$ a mitochondrial $\mathrm{Mg}^{2+}$-dependent ATPase (Turner \& Lloyd, 1971); (b) a cytosolic $\mathrm{Ca}^{2+}$ dependent ATPase isolated from a post-ribosomal supernatant fraction (Chua et al., 1976); (c) a dynein ATPase (Gibbons, 1966) which has a pH optimum of 8.5-9.0 and is dependent on the presence of $\mathrm{Mg}^{2+}, \mathrm{Ca}^{2+}, \mathrm{Fe}^{2+}, \mathrm{Co}^{2+}$ or $\mathrm{Ni}^{2+}$ for activity; and $(d)$ a $\mathrm{Mg}^{2+}$-dependent ATPase found in cell homogenates (Conner et al., 1963), the activity of which was only slightly enhanced by $\mathrm{Na}^{+}$and $\mathrm{K}^{+}$and was not inhibited by the cardiac glycoside, ouabain [Frasch et al. (1978) were also unable to find a $\mathrm{Mg}^{2+}$-dependent $\mathrm{Na}^{+} / \mathrm{K}^{+}$ATPase in Trypanosoma cruzil.

The components of mitochondrial energy conservation show remarkable similarities in most eukaryotic cell types (Lloyd, 1974) but exceptions have been noted for the protozoa. The cytochromes $c$ of $T$. pyriformis (Lloyd \& Chance, 1972), Crithidia fasciculata (Hill et al., 1971) and Acanthamoeba castellanii (Edwards et al., 1977) all have unusual difference spectra; in addition, the amino acid sequence of cytochrome $c$ of $T$. pyriformis differs considerably from that of all other known eukaryotic cytochromes $c$ (Tarr \& Fitch, 1976). The mitochondrial ATPase of Crithidia luciliae is also exceptional in that it is only partially inhibited by oligomycin and $N, N^{\prime}$-dicyclohexylcarbodiimide. Activity is not inhibited by either aurovertin or by the naturally occurring ATPase inhibitor $\left(\mathrm{F}_{1}\right.$-inhibitor protein) from beef heart mitochondria (Opperdoes et al., 1976). The mitochondrial ATPase of $C$. fasciculata is inhibited by oligomycin, venturicidin, triethyltin sulphate, $N, N^{\prime}$-dicyclohexylcarbodiimide, leucinostatin, Dio-9 and quercetin, but not by spegazzinine or by compounds which interact with the $\beta$-subunit of $F_{1}$-ATPase (Yarlett \& Lloyd, 1981).

\footnotetext{
$\dagger$ Present address: Department of Biochemistry, University College, Cathays Park, Cardiff CF1 1XL, U.K.
} 
In this paper we show that the mitochondrial ATPase of T. pyriformis is unusual in being highly resistant to inhibition by compounds which are potent inhibitors of the mammalian and yeast enzyme complexes.

\section{METHODS}

Maintenance, growth and harvesting of organisms. Tetrahymena pyriformis strain ST (obtained from Dr Y. Suyama, Department of Biology, University of Pennsylvania, Philadelphia, U.S.A.) was maintained and grown as previously described (Lloyd et al., 1971) in a medium containing $2 \%(\mathrm{w} / \mathrm{v}$ ) proteose peptone (Difco), $0 \cdot 1 \%$ yeast extract (Difco), $0.5 \%$ glucose, $5 \mu \mathrm{g} \mathrm{FeCl}_{3} \cdot 6 \mathrm{H}_{2} \mathrm{O} \mathrm{ml} \mathrm{ml}^{-1}$ and $0.1 \%$ antifoam RD emulsion (Hopkin \& Williams, Chadwell Heath, Essex, U.K.), adjusted to $\mathrm{pH} 7.2$ with $5 \mathrm{M}-\mathrm{KOH}$ (Dickinson et al., 1976). In this medium cell populations grew with a mean cell generation time of $182 \mathrm{~min}$ (range $18 \mathrm{~min}$ in 15 experiments) to a cell density of $8.0 \times 10^{5}$ (range $0.8 \times 10^{5}$ ) organisms $\mathrm{ml}^{-1}$. Organisms were harvested from cultures $(4 \mathrm{l}$ ) at a density of $2.2 \times 10^{5}$ (range $1.4 \times 10^{5}$ ) organisms $\mathrm{ml}^{-1}$ as previously described (Lloyd et al., 1971).

Disruption of organisms and preparation of mitochondria. Harvested cells were washed once in a buffer consisting of $3.2 \mathrm{M}$-sucrose, $10 \mathrm{mM}$-EGTA, $24 \mathrm{mM}$-Tris/ $\mathrm{HCl} \mathrm{pH} 7.2$, and resuspended in this buffer at $4{ }^{\circ} \mathrm{C}$ at 20-30 mg protein $\mathrm{ml}^{-1}$. The cells were disrupted by homogenization at $4{ }^{\circ} \mathrm{C}$ in a chilled $50 \mathrm{ml}$ glass homogenizer fitted with a PTFE plunger (Jencons Scientific, Hemel Hempstead, Herts. U.K.) Cell breakage was followed microscopically until about $70 \%$ breakage was achieved. Mitochondria were prepared by differential centrifugation as previously described (Turner et al., 1971).

Preparation and gel filtration of submitochondrial particles. Mitochondrial fractions (3-5 ml samples containing $10-15 \mathrm{mg}$ protein $\left.\mathrm{ml}^{-1}\right)$ were treated with ultrasound for $30 \mathrm{~s}(20 \mathrm{kHz}, 500 \mathrm{~W}$; MSE sonicator, power setting 5) to produce a suspension of submitochondrial particles. Gel filtration of submitochondrial particles was done by passage through a Sephadex G-50 column $(10 \mathrm{~cm} \times 1 \mathrm{~cm})$ eluted with preparation buffer. The particles were eluted in the void volume $(4.6 \mathrm{ml})$.

Preparation of ATPase inhibitor proteins. Suspensions of $T$. pyriformis submitochondrial particles were heated $\left(90^{\circ} \mathrm{C}\right.$ for $\left.5 \mathrm{~min}\right)$ and then cooled on ice and centrifuged $(38000 \mathrm{~g}$ for $20 \mathrm{~min})$. The supernatant containing the inhibitor protein was purified by filtration through an XM-100 membrane filter (Amicon, Lexington, Mass., U.S.A.) under $\mathrm{N}_{2}\left(1.37 \times 10^{5} \mathrm{~Pa}\right)$ at $4{ }^{\circ} \mathrm{C}$ (removing about $70 \%$ of proteins of mol. wt $\left.>20000\right)$ and concentrated by removing about $50 \%$ of the liquid by filtration through a PM-10 membrane filter (Amicon) under $\mathrm{N}_{2}\left(3.44 \times 10^{5} \mathrm{~Pa}\right)$ at $4{ }^{\circ} \mathrm{C}$. ATPase inhibitor proteins from beef heart mitochondria and Schizosaccharomyces pombe mitochondria were prepared by the same technique but purification by membrane filtration was omitted. Inhibitor peptides from all three sources were shown to be single peptides of mol. wt $<15000$ by sodium dodecyl sulphate gel electrophoresis.

Immunological assay of ATPase. Antiserum raised by injecting a rabbit with $25 \mathrm{mg} \mathrm{F}_{1}$-ATPase prepared from submitochondrial particles from $S$. pombe (Beechey et al., 1975) was kindly prepared by Dr J. Edwards (Sully Hospital, South Glamorgan, Wales).

Enzyme assays. ATPase (EC 3.6.1.3) was routinely assayed by two methods. (a) Proton release was measured using a Pye model $79 \mathrm{pH}$ meter fitted with an EIL combination micro-pH-electrode (Chance \& Nishimura, 1967). The output of the $\mathrm{pH}$ meter was connected via an amplifier to a $50 \mathrm{mV}$ potentiometric recorder. Calibration was done by adding known volumes of $100 \mathrm{~mm}-\mathrm{HCl}$. Extract was added to a stirred medium $(2 \mathrm{ml})$ at $29^{\circ} \mathrm{C}$ containing $4 \mathrm{~mm}-\mathrm{ATP}, 4.5 \mathrm{mM}-\mathrm{MgSO}_{4}$ and $10 \mathrm{mM}$-Tris/ $\mathrm{HCl} \mathrm{pH} 7.15$ with a trace of carbonic anhydrase to prevent $\mathrm{pH}$ drift caused by absorption of atmospheric $\mathrm{CO}_{2}$. (b) Extract was incubated at $29{ }^{\circ} \mathrm{C}$ in a medium ( $1 \mathrm{ml}$ ) containing $4 \mathrm{~mm}-\mathrm{ATP}, 4 \cdot 5 \mathrm{~mm}-\mathrm{MgSO}_{4}$ and $50 \mathrm{~mm}$-Tris $/ \mathrm{HCl} \mathrm{pH} 7 \cdot 15$. After the reaction was stopped by addition of $0.1 \mathrm{ml} 50 \%(\mathrm{w} / \mathrm{v})$ trichloroacetic acid, the protein was removed by centrifugation at $1200 \mathrm{~g}$ min and the supernatant was assayed colorimetrically for $P_{1}$ by the method of Fiske and Subba-Row (1925). Corrections for enzyme and substrate blanks were done as routine. All enzyme assays were performed within $7 \mathrm{~h}$ of preparation of extracts.

Protein was measured by the Lowry method with bovine serum albumin as standard.

Chemicals. ATP, carbonic anhydrase, quercetin $\left(3,3^{\prime}, 4^{\prime}, 5,7\right.$-pentahydroxyflavone) ouabain (octahydrate), EGTA, and oligomycin (approx. composition 65\% oligomycin A, 20\% oligomycin B, 15\% oligomycin C) were from Sigma. Bovine serum albumin powder was from Armour Pharmaceutical Co., Eastbourne, Sussex, U.K. Sephadex G-50 was from Pharmacia. $N, N^{\prime}$-Dicyclohexylcarbodiimide and venturicidin (approx. 4:1 mixture of venturicidin A and B) were from BDH. Citreoviridin (C7026) was from Cambrian Chemicals, Beddington Farm Road, Croydon, London. Dio-9 was from Koninklijke Nederlandsche Gist and Spiritus fabriek, Delft, The Netherlands: a solution of Dio-9 containing $1 \mathrm{mg} \mathrm{ml}^{-1}$ gives a value of $A_{303}-A_{400}=0.1$ (Guillory, 1964); on this basis the commercial product was found to be only $40 \%$ pure. 4-Chloro-7-nitrobenzofurazan was from Aldrich Chemical Co., Gillingham, Dorset, U.K. Aurovertin, triethyltin sulphate and dibutylchloromethyltin chloride were gifts from Dr D. E. Griffiths and Dr T. G. Cartledge, Department of Molecular Sciences, University of Warwick, 
Coventry, U.K. Leucinostatin (antibiotic A20668A) and efrapeptin (antibiotic A23871) were gifts from Dr R. Hamill of Lilly Research Laboratories, Indianapolis, Ind., U.S.A. Spegazzinine, a dihydroindole alkaloid, was a gift from the División de Química Orgánica Superior, Facultad de Ciencias Exactas, Universidad Nacional de La Plata, La Plata, Argentina.

\section{RESULTS AND DISCUSSION}

ATPase assays with submitochondrial particles at various pH values (Fig. $1 a$ ) indicated the presence of three $\mathrm{pH}$ optima, at $\mathrm{pH} \mathrm{6.3,7.15}$ and 7.35. The optima at $\mathrm{pH} 6.3$ and $\mathrm{pH} 7.15$ correspond with those determined for the $\mathrm{F}_{1}$-ATPase activity of mitochondria purified on density gradients (Turner \& Lloyd, 1971) and are different from the $\mathrm{pH}$ optima for dynein ATPase (Gibbons, 1966) and soluble ATPase (Chua et al., 1976). The inclusion of vanadate (as an impurity in ATP from Sigma) in reaction mixtures inhibits any contribution to ATPase activity from sarcoplasmic reticulum $\mathrm{Ca}^{2+}$-ATPase, plasma membrane $\mathrm{Ca}^{2+} /$ $\mathrm{Mg}^{2+}$-ATPase, plasma membrane $\mathrm{Mg}^{2+}$-ATPase and $\mathrm{Na}^{+} / \mathrm{K}^{+}$-ATPase but not from mitochondrial ATPase or plasma membrane $\mathrm{Ca}^{2+}$-ATPase (O'Neal et al., 1979). Insensitivity to $10 \mathrm{~mm}$-ouabain also suggested that the ATPase activity was not due to a $\mathrm{Na}^{+} / \mathrm{K}^{+}$-ATPase. Inhibition of ATPase activity by $\mathrm{F}_{1}$ inhibitor proteins from different cell types and by antiserum prepared against $\mathrm{F}_{1}$-ATPase further confirmed that the ATPase is mitochondrial (Table 1).

The optimum $\mathrm{Mg}^{2+}$ :ATP ratio, at $4 \mathrm{mM}$-ATP (Fig. 1 b) at both the $\mathrm{pH} 6.3$ and the $\mathrm{pH} 7 \cdot 15$ optima, was $1: 1.25$ for preparations of both mitochondria and submitochondrial particles. The optimum at $\mathrm{pH} 7 \cdot 15$ was used in all further work.

The specific activities of ATPase in preparations of mitochondria, submitochondrial particles and submitochondrial particles after gel filtration were in the ratio 1:1.7 (S.D. $0.45): 2 \cdot 25$ (S.D. 0.5$)$ (11 experiments) when assayed by proton release.

None of the agents known to inhibit the enzyme complex at $F_{0}$ in yeast and mammalian mitochondria (Lloyd, 1974) gave complete inhibition, even at high titres (Table 1). $N, N^{\prime}$-Dicyclohexylcarbodiimide was the most inhibitory. All preparations were 10 - to 100 -fold less sensitive to inhibitors than those from the yeast Schizosaccharomyces pombe (Lloyd \& Edwards, 1976). Similarly, the $F_{1}$-ATPase inhibitors Dio-9, efrapeptin, 4chloro-7-nitrobenzofurazan and spegazzinine gave only partial inhibition, and aurovertin, citreoviridin and quercetin were without effect. That similar results were obtained in all cases with mitochondria and submitochondrial particles indicates that it is unlikely that limited accessibility to inhibitor-binding sites leads to the small extent of inhibition observed. Gel filtration to remove any endogenous natural inhibitor did not markedly increase the maximum extent of inhibition attainable (except for that by oligomycin and $N, N^{\prime}$-dicyclohexylcarbodiimide). Thus it seems unlikely that prior occupancy by the natural inhibitor of binding sites specific for added inhibitors can explain resistance to inhibition.

The mitochondrial ATPase of T. pyriformis is thus similar in some respects to that of Crithidia fasciculata (Yarlett \& Lloyd, 1981), which lacks some inhibitor-binding sites associated with the $\beta$-subunit of $\mathrm{F}_{1}$-ATPase. It is however, strikingly different from the enzyme complex of Acanthamoeba castellanii, which possesses a full complement of inhibitor-binding sites, and is similar in many respects to the ATPases of yeast and mammals (S. W. Edwards \& D. Lloyd, unpublished results).

Comparison of the inhibitor-binding properties of ATPase of mitochondria-enriched fractions of T. pyriformis with other proton-translocating ATPases is facilitated by reference to data collected by Linnett \& Beechey (1979). Resistance to aurovertin distinguishes the mitochondrial ATPase of T. pyriformis from that of beef heart and rat liver mitochondrial ATPases and from the ATPase activity of Rhodospirillum rubrum chromatophores, but not from chloroplast ATPase, which is also resistant to aurovertin; citreoviridin inhibits beef heart mitochondrial ATPase and ATPase activity of $R$. rubrum chromatophores in a similar 


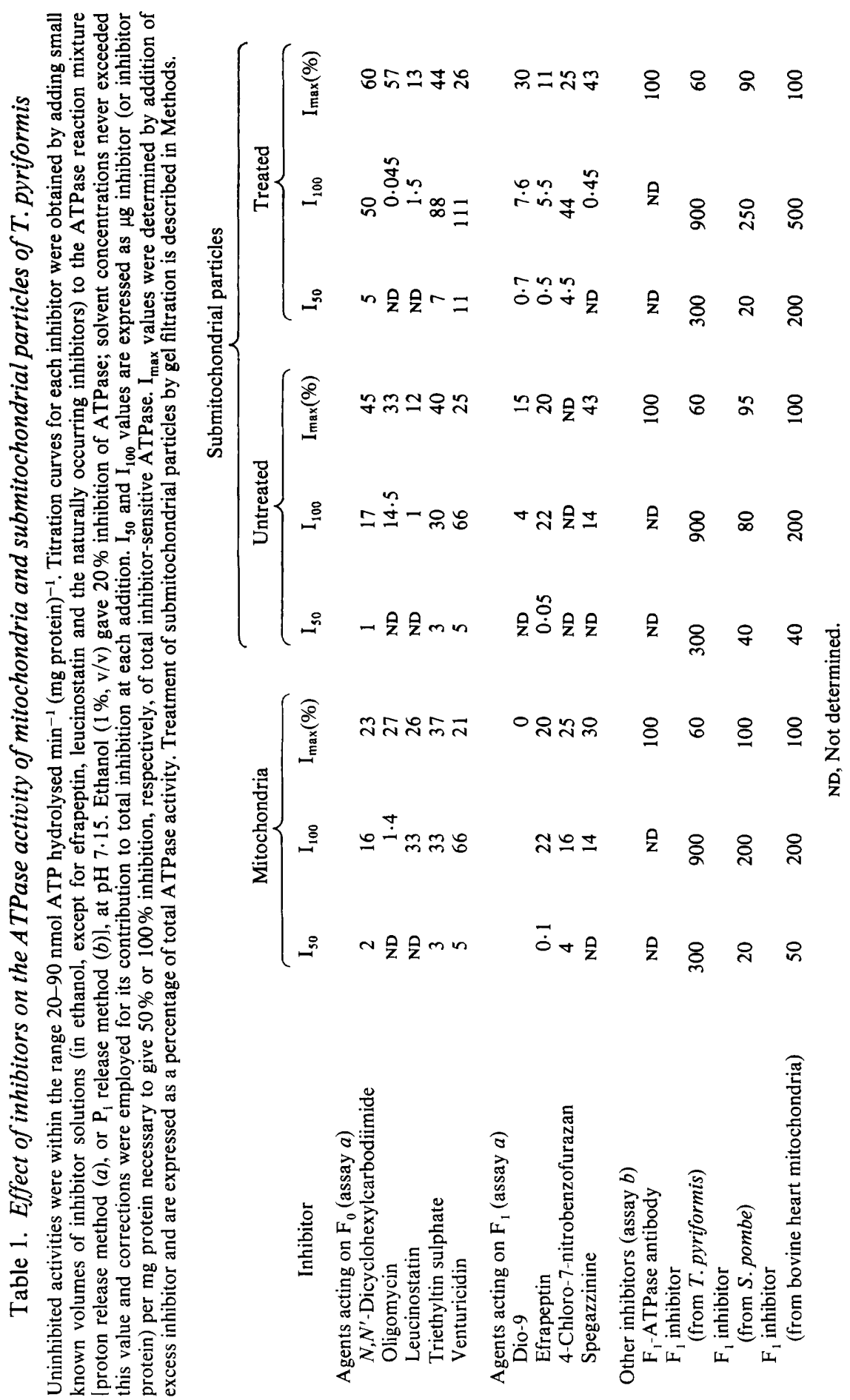





Fig. 1. Effects of $\mathrm{pH}$ and $\mathrm{Mg}^{2+}$ concentration on ATPase activity of Tetrahymena pyriformis. (a) Submitochondrial particles $\left(2.0 \mathrm{mg}\right.$ protein $\left.\mathrm{ml}^{-1}\right)$ were incubated at $29^{\circ} \mathrm{C}$ in buffer containing $4 \mathrm{~mm}$-ATP, $4.5 \mathrm{mM}^{-\mathrm{MgSO}_{4}}$ and $50 \mathrm{~mm}$-Tris. Tris/acetate buffer was used for the $\mathrm{pH}$ range $6 \cdot 0-6 \cdot 6$, and Tris $/ \mathrm{HCl}$ for the range 6.6-8.0. ATPase activity was measured by $\mathrm{P}_{1}$ release; $100 \%$ activity represents $67 \mathrm{nmol} P_{\text {i }}$ released $\min ^{-1}(\mathrm{mg} \text { protein })^{-1}$. (b) Submitochondrial particles $(1.0 \mathrm{mg}$ protein $\left.\mathrm{ml}^{-1}\right)(\mathrm{O}, O)$ and mitochondria $\left(2.0 \mathrm{mg}\right.$ protein $\left.\mathrm{ml}^{-1}\right)(\Delta, \Delta)$ were incubated at $29^{\circ} \mathrm{C}$ in buffer containing $4 \mathrm{mM}$-ATP and $50 \mathrm{mM}$-Tris, with a range of $\mathrm{Mg}^{2+}$ concentrations. The $\mathrm{pH}$ was maintained at $7 \cdot 15$ (open symbols) or 6.3 (filled symbols). ATPase activity was measured by $P_{1}$ release. Activity is expressed as a percentage of the maximum at $4.5 \mathrm{mM}-\mathrm{Mg}^{2+}$ for submitochondrial particles incubated at pH 7.15, i.e. $72 \mathrm{nmol} P_{1}$ released $\min ^{-1}(\mathrm{mg} \text { protein })^{-1}$.

manner to aurovertin; quercetin inhibits purified soluble ATPase and membrane-bound ATPase from beef heart mitochondria, spinach chloroplasts and Escherichia coli whilst $T$. pyriformis mitochondrial ATPase is totally resistant to these inhibitors. Complete inhibition of beef heart mitochondrial ATPase, spinach chloroplast ATPase, and E. coli ATPase by 4-chloro-7-nitrobenzofurazan contrasts with the incomplete inhibition observed in the present study. Efrapeptin, an antibiotic thought to react at, or close to, the active site of $F_{1}$-ATPase (Lardy et al., 1975), completely inhibits beef heart $\left[\mathrm{I}_{50}=1.2 \mu \mathrm{g}(\mathrm{mg} \text { protein })^{-1}\right]$ and yeast mitochondrial $\mathrm{F}_{1}$-ATPases and $E$. coli ATPase (at high titres), whereas chloroplast ATPase is only partially inhibited $\left(\mathrm{I}_{\max }=60-70 \%\right)$. Leucinostatin, organotin derivatives and venturicidin do not inhibit soluble $\mathrm{F}_{1}$-ATPase, but they are more potent inhibitors of rat liver and beef heart membrane-bound mitochondrial ATPases than they are of $T$. pyriformis mitochondrial ATPase.

This work was carried out during the tenure of a Science Research Council Postgraduate Studentship by M.D.U.

\section{REFERENCES}

Beechey, R. B., Hubbard, S. A., Linnett, P. E., Mitchell, A. D. \& MunN, E. A. (1975). A simple and rapid method for the preparation of adenosine triphosphatase from submitochondrial particles. Biochemical Journal 148, 533-537.

Chance, B. \& Nishimura, M. (1967). Sensitive measurements of changes of hydrogen ion concentration. Methods in Enzymology 10, 641-650.
Chua, B., Elson, C. \& Shrago, E. (1976). Identification and purification of a soluble adenosine triphosphatase from Tetrahymena pyriformis. Biochemical and Biophysical Research Communications 69, 641-647.

Conner, R. L., Chook, S. A. \& Ray, E. (1963). A cation-dependent pyrophosphatase activity in Protozoa. Journal of Cell Biology 19,15A-16A. 
Dickinson, N. R., Graves, M. G. \& Swoboda, B. E. P. (1976). Cyclic AMP metabolism in the cell cycle of Tetrahymena pyriformis. FEBS Letters 65 , 152-154.

Edwards, S. W., Chagla, A. H., Griffiths, A. J. \& LLOYD, D. (1977). The cytochromes of Acanthamoeba castellanii. Biochemical Journal 168, 113-121.

Fiske, C. H. \& Subba-Row, Y. (1925). The colorimetric determination of phosphorus. Journal of Biological Chemistry 66, 375-400.

Frasch, A. C. C., Segura, E. L. \& Cazzulo, J. J. (1978). Solubilisation and some properties of the $\mathrm{Mg}^{2+}$-activated adenosine triphosphatase from Trypanosoma cruzi. Comparative Biochemistry and Physiology 61B, 207-212.

Gibbons, I. R. (1966). Studies on the adenosine triphosphatase activity of $14 \mathrm{~S}$ and $30 \mathrm{~S}$ dynein from cilia of Tetrahymena. Journal of Biological Chemistry 241, 5590-5596.

Guillory, R. J. (1964). The action of Dio-9: an inhibitor and an uncoupler of oxidative phosphorylation. Biochimica et biophysica acta 89, 197-207.

Hill, G. C., Chan, S. K. \& SмITh, L. (1971). Purification and properties of cytochrome $c_{55}$ from a protozoon, Crithidia fasciculata. Biochimica et biophysica acta 253, 78-87.

Lardy, H. A., Reed, P. \& Lin, E. H. C. (1975). Antibiotic inhibitors of mitochondrial ATP synthesis. Federation Proceedings 34, 1707-1710.

LinNetT, P. E. \& BeECHEY, R. B. (1979). Inhibitors of the ATP synthetase system. Methods in Enzymology 55, 472-518.

Lloyd, D. (1974). The Mitochondria of Microorganisms, pp. 82-158. London: Academic Press.

LloYd, D. \& CHANCE, B. (1972). The cytochromes of mitochondria from Tetrahymena pyriformis strain ST. Biochemical Journal 128, 1171-1182.

LloYd, D. \& EDWARDS, S. W. (1976). Mitochondrial adenosine triphosphatase of the fission yeast,
Schizosaccharomyces pombe $972 \mathrm{~h}^{-}$. Changes in activity and inhibitor-sensitivity in response to catabolite repression. Biochemical Journal 160, 335-342.

Lloyd, D., Brightwell, R., Venables, S. E., ROACH, G. I. \& TURNER, G. (1971). Subcellular fractionation of Tetrahymena pyriformis ST by zonal centrifugation: changes in activities and distribution of enzymes during the growth cycle and on starvation. Journal of General Microbiology 65, 209-223.

O'Neal, S. G., Rhoads, D. B. \& RaCker, E. (1979). Vanadate inhibition of sarcoplasmic reticulum $\mathrm{Ca}^{2+}$. ATPase and other ATPases. Biochemical and Biophysical Research Communications 89, 845850.

OPPERDOES, F. R., DE RiJKe, D. \& BoRST, P. (1976). Reactions involved in energy transfer in trypanosomes. 1. Characterisation of the mitochondrial adenine nucleotide translocator and the ATPase of Crithidia luciliae. Comparative Biochemistry and Physiology 54B, 7-12.

TARR, G. E. \& Fitch, W. M. (1976). Amino acid sequence of cytochrome $c$ from Tetrahymena pyriformis phenoset A. Biochemical Journal 159, 193-199.

TuRner, G. \& Lloyd, D. (1971). The effect of chloramphenicol on growth and mitochondrial function of the ciliate protozoon Tetrahymena pyriformis strain ST. Journal of General Microbiology 67, 175-188.

Turner, G., Lloyd, D. \& Chance, B. (1971). Electron transport in phosphorylating mitochondria from Tetrahymena pyriformis strain ST. Journal of General Microbiology 65, 359-374.

YARLETT, N. \& LLOYD, D. (1981). Effects of inhibitors on mitochondrial adenosine triphosphatase of Crithidia fasciculata: an unusual pattern of specificities. Molecular and Biomedical Parasitology 3, 13-17. 